ROCZNIK PRZEMYSKI t. 57

HISTORIA z.1 (26) 2021

ARKADIUSZ STANISŁAW WIECH (Kraków)

orcid.org/0000-0003-4888-1129

\title{
PORTRET GALICYJSKIEGO \\ I MIĘDZYWOJENNEGO PRZEMYSŁOWCA. ŁUKASZ CHROBAK, KSIĄŻE ANDRZEJ LUBOMIRSKI. ORDYNAT I PRZEMYSŁOWIEC W LATACH 1882-1939, KRAKÓW 2021, SS. 278, ILUSTRACJE
}

Literatura biograficzna cieszy się obecnie dużą popularnością zarówno pośród czytelników, jak i badaczy. Dominują wśród nich pozycje bardziej popularne niż naukowe, tymczasem te ostatnie stanowią niezwykle ważny element badań historycznych. W indywidualnych losach jednostki niejednokrotnie odnaleźć możemy skumulowanie, niczym w soczewce, losy danego pokolenia. Biografowie najczęściej opisują życie i działalność osób związanych z światem kultury, polityki, nauki, zajmujących się szeroko pojętną działalnością filantropijną. W mniejszym zaś stopniu sięgają po postacie związane z przemysłem i gospodarką. Dlatego też warto odnotować i pochylić się nad wydaną przez krakowskie wydawnictwo Księgarnia Akademicka, w ramach serii „Studia Galicyjskie” (tom 7), monografią autorstwa Łukasza Chrobaka: Ksiązę Andrzej Lubomirski. Ordynat i przemystowiec w latach 1882-1939.

Żyjący w latach 1862-1953 Andrzej Lubomirski był człowiekiem rozlicznych zainteresowań. Jego działalność rozwijała się na wielu płaszczyznach: filantropijnej, kulturalnej, artystycznej, naukowej, politycznej, społecznej, gospodarczej i przemysłowej. I właśnie na tych dwóch ostatnich w swojej pracy skupił się Łukasz Chrobak. Otrzymujemy zatem studium szerokiej działalności przemysłowej ostatniego przeworskiego ordynata. Ma to swoje uzasadnienie, na które słusznie autor zwrócił uwagę, piszące we Wstępie:

Przy tak rozległych zainteresowaniach i działaniach Andrzeja Lubomirskiego należało wybrać najważniejsze kwestie związane z jego życiem. Ze wszystkich rodzajów aktywności to gospodarka była główną domeną jego działań. Nie należał do wybitnych polityków. Z kolei jego praca na rzecz Ossolineum nie polegała na kierowaniu zakładem (...), lecz ograniczała się do udostępniania rodzinnych 
pamiątek i dotowania tej instytucji, co łączyło się ze staraniami o dobrą kondycję ordynacji przeworskiej jako warunku finansowego utrzymania wydawnictwa. Zatem praca księcia przede wszystkim polegała na zarządzaniu gospodarką ordynacji i na działalności przemysłowej ${ }^{1}$.

Za główny cel swojej pracy autor obrał zatem zaprezentowanie postaci Andrzeja Lubomirskiego, jako idącego z duchem czasu przedsiębiorcy i przemysłowca, nie tylko modernizującego przeworską ordynację, ale także wywierającego niebagatelny wpływ na życie przemysłowe zarówno Galicji, jak i odrodzonej II Rzeczypospolitej. Uczynił to, poszukując odpowiedzi na sformułowane przez siebie pytania badawcze, dotyczące zarówno samej osoby księcia Lubomirskiego i jego predyspozycji do prowadzonej działalności, jak również, w szerszym ujęciu, odnoszące się również do realiów ówczesnego zarządzania instytucjami przemysłowymi, zwłaszcza w warunkach zmieniającej się sytuacji politycznej oraz gospodarczego kryzysu. Takie podejście do tematu stanowi zatem doskonały przykład studium przypadku, w którego ujęciu dostrzec możemy odbicie tego wszystkiego, co w zakresie przemysłu i gospodarki następowało w skali makro na terenie nie tylko Galicji (do 1918 roku), a poprzez to Monarchii Austro-Węgierskiej, ale i w latach istnienia II Rzeczypospolitej. Takiemu ujęciu zagadnienia odpowiadają również ramy historyczne niniejszej pracy. Rok 1882, przynoszący objęcie w zarząd ordynacji przeworskiej przez Andrzeja Lubomirskiego, oraz rok 1939, będący momentem początku II wojny światowej i kresem jej istnienia.

Monografia podzielona została na cztery rozdziały złożone z mniejszych podrozdziałów. Pierwszy z nich (Korzenie rodzinne Andrzeja Lubomirskiego. Zarys dziejów rodu Lubomirskich) stanowi rodzaj wprowadzenia do omawianego zagadnienia. Autor omawia w nim genealogię rodu Lubomirskich oraz dzieje przeworskiej linii rodu, a także odnosi się do początków powstania ordynacji i jej związków z lwowskim Ossolineum. Pozostałe trzy rozdziały odnoszą się do działalności bohatera książki w poszczególnych okresach: lat 1882-1918, a zatem czasu galicyjskiego (rozdział drugi: Działalność księcia Andrzeja Lubomirskiego w latach 1882-1918), lat 20. XX w. (rozdział trzeci: Praca i działalność na płaszczyźnie gospodarczej po odzyskaniu przez Polske niepodległości) oraz czasów kryzysu gospodarczego w latach 30 . XX w. i następujących po nim prób odbudowy, a także lat II wojny światowej i ostatnich lat życia (rozdział czwarty: Okres wielkiego kryzysu i próba odbudowy interesów). Zarysowany powyżej trzon pracy rozpoczyna - zawierający omówienie metodologii przyjętej w pracy, definicję potrzebnych pojęć (takich jak: przemysłowiec, ziemiaństwo, arystokracja), a także prezentujący stan badań i wykorzystanych w pracy materiałów archiwalnych - Wstęp, a całość wieńczy

${ }^{1}$ Ł. Chrobak, Ksiązę Andrzej Lubomirski. Ordynat i przemystowiec w latach 1882-1939, Kraków 21, s. 15. 
zawierające podsumowanie Zakończenie. Dopełnieniem jest znajdujący się w monografii niewielki, ale ciekawy materiał ilustratorski.

Czytelnik otrzymuje niezwykle interesującą i opartą na szerokiej podstawie źródłowej pracę, na którą złożyły się materiały archiwalne z polskich i ukraińskich archiwów i bibliotek, m.in. z: Archiwum Akt Nowych w Warszawie, Archiwum Głównego Akt Dawnych w Warszawie, Archiwum Narodowego w Krakowie, Archiwum Państwowego w Przemyślu, Archiwum Muzeum w Przeworsku, Biblioteki Jagiellońskiej w Krakowie, Biblioteki Polskiej Akademii Nauk w Krakowie, Zakładu Narodowego im. Ossolińskich we Wrocławiu, Biblioteki i Archiwum Muzeum-Zamku w Lańcucie, a także z Centralnego Państwowego Archiwum Historycznego Ukrainy we Lwowie oraz Lwowskiej Biblioteki im. Wasyla Stefanyka we Lwowie. Istotnymi źródłami wykorzystanymi przez autora były również materiały prasowe, jak również źródła drukowane w postaci sprawozdań z działalności różnych organizacji oraz instytucji oraz liczne wspomnienia. Wykorzystane w pracy opracowania wskazują na dobrą znajomość badanej tematyki oraz świadczą o niezwykłej skrupulatności i pracowitości autora.

Łukach Chrobak w swoich rozważaniach na temat działalności przemysłowej i gospodarczej ostatniego przeworskiego ordynata prowadzi czytelnika przez meandry biznesowych zawiłości, starając się przybliżyć nie tylko same poczynania Lubomirskiego, ale również ukazać jego motywację czy sposoby działań. Czyni to w zdecydowanie szerszej perspektywie, ukazując kontekst zarówno galicyjski, jak i całej C.K. Monarchii, a nawet odnosi się do sytuacji panującej na pozostałych ziemiach polskich pod zaborami rosyjskim i pruskim. Dobrym przykładem może być tutaj zaprezentowanie złożonej sytuacji w zakresie przemysłu cukrowniczego w Galicji, który stał się niejako podstawą gospodarczego sukcesu przeworskiej ordynacji. Zaangażowanie w niego ordynata dobrze obrazuje jego wytrwałość w dążeniu do celu, nawet jeśli wymagało to od niego poświęceń i inwestowania znacznych środków finansowych w niepewny, przynajmniej na początku, rodzaj biznesu. Postać Andrzeja Lubomirskiego śledzimy na kratach biografii w kolejnych etapach jego przemysłowej działalności. Widzimy zachodzące w nim zmiany. Otrzymawszy w spadku nie najlepiej funkcjonującą ordynację, rozpoczął proces jej szerokiego uprzemysłowienia, dzięki któremu stać się miała sprawnie działającym przedsiębiorstwem, które przynosiło zyski jego właścicielowi, ale także stanowiło m.in. finansowe zabezpieczenie istnienia takich instytucji kultury i nauki polskiej, jak lwowskie Ossolineum. Warto podkreślić, że Chrobak, pisząc o Lubomirskim, zwraca uwagę na jego społeczne zaangażowanie i wykraczające poza lokalnie przyjęte normy spojrzenie na sytuację pracowników i robotników należących do niego majątków i zakładów. Starał się zapewnić im pomoc socjalną. Doprowadził m.in. do objęcia pracowników wraz z rodzinami bezpłatną opieką medyczną, ordynacja częściowo refundowała recepty, a także zapewniała ubezpieczenia i emerytury. W odniesieniu do 
obszaru Galicji było to niezwykle nowatorskie podejście, chociaż niewątpliwie w skali europejskiej przełomu XIX i XX w. idące z „duchem czasu”. Opisując poczynania Lubomirskiego autor pozostaje jednak wobec jego postaci krytyczny i nie daje się „uwieść" bohaterowi. Pisze o biznesowych niepowodzeniach lub błędnych decyzjach przemysłowca (chociażby personalnych, jak w przypadku jego pełnomocnika do spraw fabryki maszyn „Perkun”), a także jednoznacznie ocenia chociażby prezentowane przez swojego bohatera przemyślenia na temat ekonomii, pisząc, że ten: „nigdy nie był znaczącym twórcą myśli ekonomicznej, nie pozostawił po sobie wielu istotnych publikacji”'. Ukazując aktywność ordynata na forum instytucji politycznych lub różnorakich stowarzyszeń, jak chociażby Galicyjskiego Towarzystwa Gospodarczego we Lwowie, zwraca uwagę $\mathrm{w}$ jego zaangażowanie $\mathrm{w}$ podniesienie stanu galicyjskiej gospodarki oraz przemysłu oraz w wiarę w możliwości, jakie stoją przed tymi dziedzinami, szczególnie w konfrontacji z wiedeńskim traktowaniem Galicji jako miejsca zbytu dla produktów z innych części monarchii. Opisuje również dążenie do poprawy galicyjskiej infrastruktury kolejowej, jej rozbudowy oraz większego wykorzystania do celów aprowizacyjnych i gospodarczych. Podkreślone zostało również zaangażowanie księcia w odbudowę Galicji po zniszczeniach wojennych i podejmowanie przez niego inicjatywy zarówno w czasach końca austro-węgierskiej monarchii, jak i już w odradzającej się Polsce. Ciekawym wątkiem, który pojawia się również na kartach książki, jest ukazanie przez Chrobaka osoby Lubomirskiego na tle innych, próbujących odnieść sukces w przemyśle arystokratów. Szczególnie dobrze widać to w okresie międzywojennym, kiedy to Lubomirski, w przeciwieństwie do innych mu podobnych, nie prowadził nazbyt wystawnego życia, ale koncentrował się na inwestowaniu w posiadane aktywa, dzięki czemu był w stanie zabezpieczyć odpowiednie środki finansowe, prowadzić sprawną politykę i umiejętnie zarządzać swoimi interesami, broniąc ich przed zakusami konkurencji. Takie podejście stało się niezwykle ważne i cenne w obliczu wielkiego kryzysu ekonomicznego I połowy lat 30 . XX w. oraz następującego po nim czasu stopniowej odbudowy, przerwanej przez wybuch II wojny światowej we wrześniu 1939 r. Książe Andrzej Lubomirski w biografii Chrobaka jest postacią niezwykle żywą i zaciekawia od samego początku lektury. Zaprezentowane płaszczyzny jego działań, związków rodzinnych, ale i nierzadko występujących na tle podejmowanych przez niego decyzji biznesowych, różnych konfliktów i sporów (jak chociażby z bratem Kazimierzem Lubomirskim) sprawiają, że pracę czyta się łatwo i z dużym zainteresowaniem.

$\mathrm{Z}$ recenzenckiego obowiązku na koniec chciałbym powiedzieć o pewnych pojawiających się w pracy usterkach, które bynajmniej nie wpływają na końcową jak najbardziej pozytywną ocenę książki, a które wychwyciłaby bardziej uważna redakcja monografii. Pozwolę sobie tutaj podać kilka drobnych przykładów.

\footnotetext{
${ }^{2}$ Ł. Chrobak, op. cit., s. 110.
} 
Prezentując stan badań nad Andrzejem Lubomirskim Łukasz Chrobak słusznie zwrócił uwagę, że postać ta nie doczekała się jak dotąd większego opracowania. W tekście głównym Wstępu pisze, że do tej pory ukazały się w zasadzie jedynie cztery publikacje mu poświęcone, tymczasem już przypisie do tego stwierdzenia wymienia ich więcej, wskazując zarówno bardziej popularne biogramy, jak i teksty o raczej naukowej proweniencji. Zabrakło tutaj zatem pewnej konsekwencji, korelacji pomiędzy treścią tekstu głównego a treścią przypisu, czemu zapobiegałby jednak wspominana już przed momentem lepsza redakcja książki. Również we Wstępie zabrakło jasnego i precyzyjnego wyjaśnienia przyjętej cezury czasowej (lata 1882-1939). Jest ona oczywiście zrozumiała, ale powód jej wyboru nie został wyraźnie wyartykułowany i wyjaśniony. Czytając rozważania autora czasami można odnieść wrażenie pewnego pojawiającego się w pracy chaosu, kiedy np. pisząc o tych samych osobach - raz podkreśla ich tytuły i zajmowane pozycje, innym razem pomija - co czasem całkowicie zmienia kontekst przytaczanych w tekście wyrażanych przez nich opinii. Np. Jan Mycielski, będący przez jakiś czas dyrektorem generalnym ordynacji, pojawia się jako dyrektor, hrabia, właściciel ziemski, niemalże zaufany przyjaciel. Oczywiście we wszystkich tych „wcieleniach" mógł wszakże występować, jednakże sposób przywoływania jego osoby budzić może u czytającego pewne zagubienie i pytanie, czy autor pisze o tej samej osobie. Nie ustrzegł się autor również pewnych powtórzeń, bowiem zdarza mu się o pewnych kwestiach pisać kilkukrotnie. Zdarzyło mu się także nieprawidłowo przypisać błąd w nazwie krakowskiej ulicy św. Jana Andrzejowi Lubomirskiemu, który w pisanym przez siebie liście użył jej zniekształconej, potocznej formy „Stojańska”. Nie są to jednakże jakieś znaczące potknięcia i, jak już zostało zauważone, zdecydowanie wyeliminowałaby je lepsza redakcja książki.

Reasumując należy podkreślić, że poświęcona Andrzejowi Lubomirskiemu książka Łukasza Chrobaka stanowi dobry przykład naukowej biografistyki historycznej, w której otrzymujemy nie tylko wnikliwe studium jednostki, ale również ukazane zostało szerokie tło panujących stosunków społecznych oraz zachodzących przemian gospodarczych na przestrzeni kilku różnych od siebie epok. Mamy bowiem do czynienia z biznesmenem działającym w całkiem różnych warunkach austriackiej Galicji oraz II Rzeczypospolitej, dodatkowo zaś zmagającym się z trudem odbudowy majątku i posiadanych przedsiębiorstw po Wielkiej Wojnie, a następnie zmagającego się z licznymi problemami w warunkach olbrzymiego kryzysu gospodarczego lat 30 . XX w. Wszystko to zostało przez autora prezentowanej pracy skrupulatnie i rzeczowo omówione, a zasygnalizowane uprzednio uwagi nie wpływają na pozytywną ocenę książki, stanowiącej świetny punkt wyjścia do dalszych, pogłębionych badań nad życiem Andrzeja Lubomirskiego. Na plus należy także zaznaczyć, że wydało je nie niszowe, lokalne wydawnictwo, ale cieszące się uznaniem w środowisku naukowym, dzięki czemu monografia ma szansę trafić do szerszego 
grona czytelników, zarówno naukowo zajmujących się zagadnieniami z zakresu biografistyki historycznej lub historii gospodarczej, jak i pasjonatów dziejów Galicji i okresu międzywojennego. 